\title{
Patriarki Domestik Novel Perempuan Berkalung Sorban Karya Abidah El Khalieqy
}

\author{
Hesty Kusumawati \\ Sekolah Tinggi Agama Islam Negeri Pamekasan
}

\begin{abstract}
Keywords:
patriarchy; novel
\end{abstract}

\begin{abstract}
The symptoms of patriarchy open space controversy due to the emergence of violent men over women at once into the wetlands for the author to dismantle, even readers in order to build awareness of arif in facing the sides of life nuances of patriarchy. Women Berkalung Turbans works Abidah El Khalieqy loaded with patriarchy. This study mengolaborasikan the theory of domination, patriarchy, and violence in the realm of Sociology literature. Writers in its implementation be flexible over existing theories to be more critical and not stuck in one perspective. The results of the analysis showed that the patriarchal Women Berkalung Turbans as follows: 1). the domestic violence directly marked Patriarchal presence of actions, deeds, and the behavior of injure, damage, and destroyed with the intent to legitimize power, and 2). The patriarchal domestic violence indirectly signaled the presence of dirty sayings, not worthy, and deviate from the norm with the aim of influencing the mindset and psychic, so woke up the image that men are more important than women.
\end{abstract}

\section{Kata kunci:}

Patriarki; novel

\begin{abstract}
Abstrak:Gejala patriarki membuka ruang kontroversi akibat munculnya kekerasan laki-laki atas perempuan sekaligus menjadi lahan basah bagi pengarang untuk membongkar, bahkan membangun kesadaran pembaca agar arif dalam menyikapi sisi-sisi kehidupan bernuansa patriarki. Perempuan Berkalung Sorban karya Abidah El Khalieqy sarat dengan patriarki. Kajian ini mengolaborasikan teori dominasi, patriarki, dan kekerasan dalam ranah sosiologi sastra. Penulis dalam implementasinya bersikap fleksibel atas teori yang ada agar lebih kritis dan tidak terjebak dalam satu perspektif. Hasil analisis menunjukkan bahwa patriarki Perempuan Berkalung Sorban sebagai berikut: 1). Patriarki domestik kekerasan langsung ditandai adanya tindakan, perbuatan, dan perilaku merusak, melukai, dan menghancurkan dengan maksud melegitimasi kekuasaan, dan 2). Patriarki domestik kekerasan tidak langsung ditandai adanya ucapan kotor, tak layak, dan menyimpang dari norma dengan tujuan mempengaruhi pola pikir dan psikis, sehingga terbangun citra bahwa laki-laki lebih penting dibandingkan perempuan.
\end{abstract}

Alamat Korespondensi:

E-mail: hestykusumawati4@gmail.com (Hesty Kusumawati)

\section{Pendahuluan}

Fenomena kehidupan manusia amat kompleks, beragam dan penuh nuansa. Manusia menampilkan karakteristik bertindak, berpikir, dan merasakan apa yang terjadi di sekitarnya. Perbedaan karakteristik manusia menciptakan adanya pola pikir dan pola tindak yang berbeda, termasuk dalam kasus-kasus yang berhubungan dengan nuansa patriarki yang merambah dalam segala aspek kehidupan, bahkan memasuki kelompok primer yang paling penting dalam masyarakat, yakni kelompok yang menamakan dirinya sebuah keluarga atau sebuah group yang terbentuk dari perhubungan laki-laki dan perempuan. Lebih-lebih keluarga yang melalui pernikahan dengan cara paksaan, status, kekerabatan, dan materialistik. Gejala yang demikian bukan hal baru dalam kehidupan sehari-hari di masyarakat yang multikultur dan masih mempertahankan aspek-aspek budaya.

Patriarki menurut Sugihastuti dapat disederhanakan menjadi kekuasaan pria atas wanita, baik dalam dunia publik maupun privat atau domestik (Sugihastuti, 2009). Patriarki dalam konteks domestik, ternyata tidak hanya dialami oleh masyarakat abangan, namun terjadi pula pada keluarga pesantren, yang notabene sudah banyak makan garam tentang membangun keluarga sakinah, mawadah, dan warohmah. Fenomena kehidupan yang demikian menjadi daya tarik pengarang untuk dijadikan bahan kepenulisan, 
namun pengarang menyampaikannya melalui kolaborasi imajinasi dan realita, sehingga ada ruang manipulasi yang perlu dikritisi, diinterpretasi, dan dideskripsikan kembali oleh pembaca atau peneliti sastra. Karya sastra dengan demikian mengandung konsepsi dunia pengarang dalam memandang bahan atau mengkonstruksi gagasan-gagasan baru sebagai respon atau refleksi terhadap bahan tersebut. Tugas pengarang dalam konteks ini menurut Kurniawan adalah dalam rangka untuk membangun konsepsi tentang dunia pengarang maupun memodifikasi (Kurniawan, 2012). Ratna menegaskan kembali bahwa kualitas tugas pengarang bergantung pada kualitas manipulasi medium bahasa, sehingga mencapai tujuan akhir sebagai motivator ke arah aksi sosial yang lebih bermakna (Ratna, 2013).

Pengarang dalam memandang realitas sebagai bahan atau memanfaatkan bahasa dalam karyanya menggunakan aktivitas pengetahuan sekaligus kekuatan intuitif-imajinatif, sehingga tidak lepas dari dinamika kehidupan yang melingkupi dirinya. Gramsci dalam Kurniawan menjelaskan bahwa hubungan dinamika kehidupan pengarang dan kondisi sosial atau kenyataan sosial bersifat saling mempengaruhi (Kurniawan, 2012). Pengarang mendapat ruang seluas-luasnya dalam memanipulasi kondisi sosial dengan segala peristiwa serta membuat apologi-apologi baru sesuai dengan keluasan pengalaman dan ketajaman pandangannya terhadap sisi-sisi kehidupan yang multikompleks, sedangkan kondisi sosial atau kenyataan sosial menawarkan sesuatu yang memungkinkan dapat menghadirkan makna baru, makna yang sebelumnya tidak terpikirkan.

Perempuan Berkalung Sorban karya Abidah El Khalieqy menggambarkan adanya perempuan (Annisa) yang mengalami perlakuan tidak adil serta banyak mengalami kekerasan, terutama dalam kehidupan rumah tangga akibat adanya dominasi patriarki atau kekuasaan laki-laki atas perempuan, baik yang dilakukan oleh saudara laki-laki, bapak, dan laki-laki lain yang hadir dalam kehidupan Annisa seharihari. Patriarki dalam nuansa kekerasan yang dilakukan oleh saudara laki-laki, bapak, maupun laki-laki lain menimpa pada tokoh Annisa, perempuan yang memiliki identitas diri sebagai saudara perempuan, anak, maupun perempuan lain. Penulis merasa bahwa ada kesenjangan yang mengada antara hasil bidikan pengarang dengan fenomena dominasi patriarki dalam kenyataan yang sebenarnya. Penulis dalam konteks ini tidak bermaksud mementahkan kembali hasil refleksi pengarang terhadap kehidupan bernuansa dominasi patriarki di lingkungan pesantren, namun keliaran imajinasi pengarang dapat saja dipertanyakan kembali karena akan menggiring ke arah munculnya kontroversi tekstual yang sangat delematis, apalagi pembaca berada pada posisi sebagai kaum laki-laki di dunia pesantren.

\section{Metode}

Penelitian ini menggunakan metode deskriptif kualitatif. Riset ini bersifat deskriptif dan menggunakan pendekatan induktif. Penelitian ini mendeskripsikan analisis mengenai patriarki domestik konteks kekerasan secara langsung dan menganalisis patriarki domestik konteks kekerasan secara tidak langsung ditandai oleh adanya tindakan, perbuatan, dan perilaku nonfisik dalam Novel Perempuan Berkalung Sorban karya Abidah El Khalieqy.

\section{Hasil dan Pembahasan}

\section{Hasil Penelitian}

Dominasi merujuk pada otoritas yang dimiliki suatu pemerintah dalam mengatur dan mengkoordinasikan negara atau kelompok sosial dibawahnya dengan tujuan menjaga stabilitas. Jenks menjelaskan bahwa dominasi dalam pandangan sosiologi ditempatkan sebagai gambaran kongkrit situasi yang mampu dikonstruksi sebagai bagian yang tidak dapat terpisahkan dari aturan-aturan kelompok sosial untuk mempertahankan kekuatan ide (Jenks, 2013). Dominasi bersifat otoriter dalam mempertahankan sebuah posisi sebagai penguasa atas negara yang lebih kecil atau kelas-kelas sosial yang berada di bawahnya. Dominasi menurut Kurniawan bertujuan untuk membangun sebuah hegemonik, yakni pola kepemimpinan negara dalam mengatur dan mengkoordinasikan negara lain secara politis, sehingga menciptakan ketaatan dan kepatuhan melalui kekuatan utama atau hegemonik (Kurniawan, 2012).

Dominasai atau kekuasaan dengan kata lai merupakan upaya-upaya mempengaruhi pihak terdominasi baik secara langsung maupun tidak langsung atau perilaku dan ucapan atau fisik dan psikis agar pihak terdominasi dapat menerima dominasi dan bertindak untuk kepentingan yang mendominasi. Pihak terdominasi pada akhirnya tidak hanya menerima, namun mereka diharapkan mampu membangun opini publik atau kognisi sosial tentang sebuah legitimasi atas dominasi yang diwacanakan. Pilliang dalam 
Sunanto, mendefinisikan patriarki sebagai konsep yang mengacu pada satu kondisi bahwa segala sesuatu diterima secara fundamental dan universal sebagai dominasi kaum laki-laki (Sunanto, 2011). Keberterimaan satu kondisi laki-laki sebagai subjek yang mendominasi atas objek terdominasi melegitimasi adanya budaya patriarki yang menciptakan hubungan ketidaksetaraan antara laki-laki dan perempuan yang kemudian dianalogikan dalam hubungan oposisi biner. Oposisi biner merujuk pada pasangan gagasan yang saling bertentangan yang diklaim para teoritisi sosial sebagai dasar pemikiran manusia dan struktur masyarakat, yang dalam konteks ini ditujukan kepada keberagaman posisi yang berlawanan antara laki-laki dan perempuan. Posisi yang berlawanan itu menempatkan laki-laki menjadi pihak yang mendominasi karena adanya faktor kekuasaan. Moi dalam Sugihastuti menjelaskan bahwa oposisi biner menciptakan oposisi antara maskulinitas dan femelitas (Sugihastuti, 2009).

Laki-laki sebagai subjek yang mendominasi dan perempuan sebagai objek yang dikuasai lebih berkaiatan dengan konstruksi sosial yang merupakan hasil pertarungan ideologi antara kelas-kelas sosial dalam masyarakat dibandingkan dengan masalah fisik maupun biologis. Dengan kata lain, identitas kekuasaan laki-laki atas perempuan dibentuk oleh kultural, yaitu oleh lingkungan yang melingkupinya. Hal itu menyebabkan sifat kuat laki-laki tidak terbentuk secara alamiyah, tetapi lingkunganlah yang kemudian memosisikan laki-laki sebagai pihak yang mendominasi. Dengan posisi laki-laki yang mendominasi maka budaya partiarki dalam konteks dominasi partiarki dapat tercipta Ketidakseimbangan hubungan sosial keluarga yang berada dalam nuansa patriarki dapat menimbulkan ketegangan maupun konflik sosial keluarga yang memojokkan kaum perempuan dan pada akhirnya menyebabkan terjadinya tindak kekuasaan laki-laki atas perempuan melalui kekerasan.

Ciciek menyatakan bahwa kekerasan biasanya terjadi di dalam kehidupan bermasyarakat akibat adanya perbedaan status dan kekuasaan, baik dari segi ekonomi, kekuatan fisik, maupun status sosial sekaligus adanya pemaksaan kehendak untuk diikuti melalui berbagai cara (Ciciek, 2005).

Kekerasan menurut Ahmadi adalah bentuk lanjutan sebuah konflik berupa luapan perasaan yang memunculkan keinginan untuk mewujudkan sebuah tindakan menghancurkan lawan atau pihak lain, baik secara langsung maupun secara tidak langsung (Ahmadi, 2007). Dominasi patriarki dalam konteks kekerasan menyaran pada makna proses atau usaha atau sesuatu yang berhubungan dengan keras yang dilakukan oleh orang yang mendominasi. Pada kajian ini orang yang mendominasi adalah laki-laki dalam sebuah keluarga atau rumah tangga terhadap perempuan, baik sebagai saudara, ayah, dan laki-laki lain, baik kekerasan berupa ucapan, tindakan, dan perilaku. Dominasi patriarki domestik dalam konteks kekerasan dengan demikian dapat mengganggu dan membunuh karakter karena dilakukan secara langsung maupun secara tidak langsung melalui perasaan dan kejiwaan atau bersifat psikis dan melalui sentuhan fisik atau jasmani. Pola kekuasaan dominasi partiarki domestik menurut Giddens dalam Scott, berakar diranah privat dalam rumah tangga dan keluarga dengan cara-cara yang penuh dengan kekerasan, meskipun secara terang-terangan maupun samar (Scott, 2011). Dominasi patriarki konteks kekerasan menyaran pada tindakan perilaku maupun ucapan pihak yang mendominasi atau tokoh laki-laki yang dapat merusak pola pikir serta pola tindak tokoh perempuan, baik secara langsung maupun secara tidak langsung yang ada dalam novel Perempuan Berkalung Sorbankarya Abidah El Khalieqy, yang dalam hal ini dialami oleh tokoh Anisa, sehingga ia menjadi interior.

Karya sastra ditempatkan sebagai dunia rekaan yang menggambarkan kehidupan dalam kerangka cermin masyarakat yang pemaknaannya tidak dipisahkan dari lingkungan, kebudayaan, dan peradaban yang menghasilkannya. Karya sastra sebagai dunia rekaan bukan hanya menggambarkan kehidupan, namun disebalik gambaran itu terselip fenomena kehidupan yang mesti disikapi secara kritis oleh sang pembaca karena pengarang memiliki pandangan dunia tentang fenomena, termasuk fenomena yang berkenaan dengan dominasi patriarki. Fenomena dominasi patriarki merupakan sebuah tradisi atau konstruksi sosial yang sudah mengakar dalam kehidupan. Laki-laki dalam budaya patriarki dianggap sebagai kelas yang lebih unggul dan lebih berkuasa, sementara perempuan dianggap sebagai kelas rendah yang hanya menangani masalah domestik, namun laki-laki dalam masalah domestik memiliki peran kontrol. Laki-laki hanya memerintah sekaligus memaksa keinginannya, bahkan dirinya dianggap lebih mampu dalam hal urusan-urusan di luar domestik.

Dominasi patriarki menurut Suharto menempatkan laki-laki lebih tinggi dan berkuasa, sehingga ia dapat bergerak bebas dan dengan cara apapun yang dianggapnya sebagai bagian dari identitas kekuasaannya. Laki-laki lebih superioritas dibidang publik dan merasa lebih bergengsi daripada pekerjaan domestik. Hal ini menjadi alasan bagi laki-laki untuk mengukir dominasinya di dalam masyarakat atau keluarga (Suharto dan Sugihastuti, 2010). Kekuasaan laki-laki atas perempuan menciptakan relasi dominasi yang sering menjadi bahan dasar penciptaan sebuah karya sastra. Persoalan dominasi patriarki menurut Sugihastutik berangkat dari mitos-mitos yang menguntungkan pihak laki-laki sebagai kelompok yang mendominasi (Sugihastuti, 2009). Laki-laki sudah sejak awal memosisikan dirinya dalam niat kemenangan atas perempuan, sehingga memunculkan kontroversi dan kritik pedas dari 
kelompok-kelompok yang ingin menghapus dan menyadarkan bahwa penempatan posisi laki-laki sebagai pihak yang mendominasi bukanlah kodrat Tuhan. Kekuasaan laki-laki atas perempuan menimbulkan gejolak yang sangat luas, yang berakibat pada munculnya pencitraan wanita dalam karya sastra. Munculnya pencitraan tersebut untuk mengimbangi adanya tradisi patriarki yang dominan yang notabene selalu menekan menyalahtafsirkan dan menyepelekan perempuan.

\section{Pembahasan}

Dominasi patriarki domestik sering terjadi di rumah tangga atau keluarga, baik dilakukan oleh saudara laki-laki, bapak, dan laki-laki lain terhadap saudara perempuan, ibu, atau perempuan lain. Dominasi patriarki tersebut dapat melalui paksaan, penekanan, dan tindak kekerasan baik secara langsung maupun secara tidak langsung. Dominasi patriarki domestik konteks kekerasan langsung (direct violence) menyaran pada tindakan berupa perilaku fisik sebagai kekuasaan laki-laki yang diimplementasikan melalui luapan perasaan yang memuncak pada keinginan untuk mencederai atau melukai orang lain dengan sengaja. Dominasi patriarki domestik konteks kekerasan langsung dapat terjadi pada waktu dan tempat yang memiliki peluang untuk melakukannya baik secara sadar maupun tidak sadar. Fenomena dominasi patriarki domestik konteks kekerasan seperti ini banyak terjadi dalam kehidupan rumah tangga sehari-hari karena manusia sudah banyak melakukan penyimpangan terhadap norma dan nilai-nilai agama, etika, sosial. Kekerasan berwujud fisik, ragawi, dan badani dapat membawa pelakunya ke ranah pelanggaran, baik dari sudut pandang agama maupun hukum, meskipun berada dalam lingkungan keluarga.

Pengarang dalam karyanya sering menjadikan fenomena kekerasan ini dalam mengolah cerita, khususnya kekerasan langsung yang terjadi dalam nuansa dominasi patriarki. Fenomena dominasi patriarki konteks kekerasan dianggap sebagai bahan sastra yang mampu menawarkan pilhan-pilihan sebagai bagian dari refleksi penyadaran atas fenomena kehidupan yang ada. Temuan data berikut menggambarkan adanya hal tersebut.

"Lelaki itu duduk di atas kursi rotan sambil mengisap rokok kretek dengan begitu nikmatnya. Asapnya melayang-layang ke udara memenuhi ruang tamu. Sesekali, sewaktu aku datang mendekat, asap itu menabrak muka dan menyusup ke dalam rambutku. Ia tertawa melihat reaksiku yang begitu sebal dengan gulungan ular kabut yang keluar dari mulutnya. Malah ia sengaja menyemburnyemburkan asap itu dari mulutnya ke mukaku, ke leherku, juga kearah dadaku." (Khalieqy, 2009: 95) Dominasi patriarki konteks kekerasan yang dilakukan oleh suami terhadap istri dalam kutipan di atas dilakukan secara langsung karena sang suami secara sengaja menyembur-nyemburkan asap rokok ke muka, leher, dan dada tokoh aku (Annisa, sang istri). Samsudin dengan sengaja melakukan hal tersebut tanpa ada rasa kasihan, bahkan ia merasa senangdan tertawa melihat istrinya yang begitu sebal atas perbuatannya itu. Ia menampakkan kekuasaannya atas sang istri bahwa dirinya dapat melakukan apa saja sesuka hatinya. Ia pun merasa menguasai atas segala apa yang melekat pada tubuh sang istri, sehingga memperlakukan sang istri sebagai boneka yang dapat diguling-gulingkan tubuhnya secara paksa. Samsudin merasa berkuasa penuh dengan cara tanpa rasa kasihan dan kelembutan mempreteli pakaian yang menempel di badan istrinya, bahkan ia semakin buas dan garang dengan mencengkram bahu sang istri sekaligus menekan kedua tangannya. Berat badannya juga menindih tubuhnya, hingga sang istri tak dapat bertahan dan merasakan sebagai sebuah peluru karet yang menembus dadanya. Pernyataan tersebut dapat dilihat pada kutipan teks berikut:

"Ia membuang 39ading39 rokok dan serta merta di luar pikiranku, laki-laki bernama Samsudin itu meraih tubuhku dalam gendongannya. Lalu membawaku ke kamar dan menidurkanku di atas ranjang. Kemudian berusaha merayuku dengan suara lelaki di masa kerajaan Majapahit. Lalu mengguling-gulingkan tubuhku dengan paksa. Dengan paksa pula ia buka bajuku, dan semua nempel di badan. Aku meronta kesakitan tetapi iakelihatan semakin buas dan tenaganya semakin lama semakin berlipat-lipat. Matanya mendelik kewajahku. Kedua tangannya mencengkram bahuku sekaligus menekan kedua lenganku. Beban gajihnya begitu berat menindih tubuhku hingga semuanya menjadi tak tertahankan.Seperti ada peluru karet yang menembus badanku. (Khalieqy, 2009: 96-97)

Samsudin tambah menjadi, ia menekan dada kiri istrinya dengan keras meskipun sang istri mengeluh kesakitan, namun dirinya sama sekali tak merespon dan tak menanggapi rasa keluh sakit sang istri. Laki-laki itu merasa telah berada pada posisi yang menang karena merasa telah berhasil menyakiti sang istri dengan caranya sendiri, sementara sang istri tak mampu melawannya. Dominasi patriarki tersebut dilakukan oleh laki-laki sebagai sang suami terhadap sang istri secara langsung dengan penuh kekerasan. Kutipan di bawah ini menunjukkan adanya pernyataan tersebut. 
“O, ya, tahu apa kau tentang perilaku muslim, istriku sayang?" Sambil mencemooh, tangan kanannya bergerak kearah dada kiriku dengan keras. Aku kembali menjerit kesakitan. Tetapi ia sama sekali tak bereaksi dengan kesakitanku. Mungkin karena ia telah berhasil menyakitiku dengan permainannya." (Khalieqy, 2009: 97)

Kekerasan secara langsung dalam nuansa dominasi patriarki yang dilakukan oleh Samsudin kepada istrinya kadang-kadang berlangsung secara diam-diam, namun pada akhirnya tambah menjadi.Ia tetap saja mempergunakan kekerasan dalam menggauli Annisa, bahkan dengan cara memaksa agar Annisa mau melayani di lantai tanpa memberi kesempatan untuk bernafas karena dengan mulutnya yang berbau asap rokok menjepit mulut sang istri tanpa berpikir bahwa apa yang dilakukan benar-benar menyakiti sang istri. Kutipan berikut memberikan gambaran yang demikian, meskipun kekerasan yang dilakukan dalam konteks ini tidak separah yang dilakukan sebelumnya. Akan tetapi, tetap saja dikategorikan sebagai wujud kekerasan sebuah dominasi patriarki karena dilakukan dengan cara-cara menyakitkan.

"Sering ketika aku sedang mengepel lantai, ia datang diam-diam dari belakang, mendekapku, mencumbuiku dan memaksaku untuk bermain cinta di lantai itu juga tanpa memberi kesempatan kepadaku, bahkan sekedar untuk bernafas dari jepitan mulutnya yang dipenuhi oleh bau asap rokok. "Bukankah begini lebih mesra, Annisa?"

"Kau menyakitiku, Samsudin! Kau hanya tahu cara menyakiti seseorang” (Khalieqy, 2009: 102).

Keganasan dan kegarangan Samsudin terhadap istrinya ternyata tanpa akhir sebab ia mengulangi kembali dengan cara yang lebih keras sebagai bagian dari dominasinya atas perempuan. Samsudin terus mendesak sampai vagina Annisa nyeri dan perih hingga ke seluruh tubuhnya, bahkan ia seperti drakula yang melahap mangsanya melalui gigitan bahu dan leher. Lebih parah lagi, ia merasa berkuasa atas tubuh itu dari segala sisi untuk dicengkram dan dicakar seperti kambing kurban yang berada di tangan seorang penjagal. Pernyataan tersebut dibuktikan oleh adanya kutipan di bawah ini.

"Lalu ia mendesak dan terus mendesak. Sampai farjiku terasa sakit hingga nyeri dan perihnya menjalar ke seluruh tubuh. Dalam keadaan seperti itu, kelakian Samsudin semakin menjadi, lalu menggigit bahu dan leherku seperti layaknya drakula. Bahkan ia juga memilih sesukanya bagian-bagian mana dari tubuhku untuk di cengkram. Dicakar-cakar semaunya, seakan aku ini kambing kurban yang sedang berada di tangan seorang penjagal". (Khalieqy, 2009: 102).

Gambaran kekerasan yang dilakukan oleh Samsudin sebagai cerminan dominasi patriarki terhadap sang istri diketahui pula dari kutipan berikut, yakni kutipan yang menunjukkan adanya keleluasaan laki-laki dalam memperlakukan perempuan. Samsudin dengan kekuatan tubuhnya memanfaatkan kelemahan istrinya, yakni dengan cara menampar, mencekik, dan menyambak rambutnya secara biadab. Tidak sampai di situ, ia pun meludahi wajahnya berkali-kali, padahal ludahnya itu benarbenar berbau busuk. Akan tetapi, ia tak peduli atas semua yang dilakukannya, bahkan Samsudin meninggalkan begitu saja sang istri yang tak berdaya.

"Setelah menampar, mencekik dan menjambak rambutku dengan penuh kebiadaban, setelah melihat tenagaku lemas tak berdaya, ia pergi sambil meludahi wajahku berkali-kali. Busuk sekali bau ludahnya". (Khalieqy, 2009: 103)

Dominasi patriarki domistik konteks kekerasan sebenarnya bukan hal baru bagi Annisa karena berbagai kekerasan yang dilakukan oleh suaminya pada dasarnya merupakan rentetan panjang yang berawal di malam pertama sebagai pengantin baru. Samsudin pada malam pertama sudah menampakkan kegarangannya. Ia seperti lembu yang melihat rumput hijau untuk disantapnya. Tidak seperti biasanya yang dialami oleh para pengantin baru, yang mengawali persetubuhan dengan kelembutan dan kasih sayang. Samsudin melepas dengan cara kasar pakaian Annisa dan mendekapnya kuat-kuat tubuh Annisa untuk melampiaskan nafsu laki-lakinya hingga sang istri kesakitan, nyeri, dan ketakutan.

Dominasi patriarki domestik konteks kekerasan tidak langsung pada hakikatnya dilakukan oleh pihak yang mendominasi (laki-laki) kepada pihak terdominasi (perempuan) dengan tujuan untuk menghancurkan mental dan menyinggung perasaan perempuan. Hal ini sependapat dengan pandangan Ahmadi yang menjelaskan bahwa kekerasan tidak langsung dilakukan melalui tindakan verbal untuk melukai kejiwaan dan menyinggung perasaan orang lain (perempuan) (Ahmadi, 2007). Kekerasan dalam hubungannya dengan dominasi patriarki bersifat psikis atau mental, yakni berhubungan dengan kekarasan nonfisik atau tidak bersifat ragawi dan jasmaniah, sehingga akibat kekerasan bentuk ini lebih bertahan lama. Kekerasan tidak langsung dapat dilakukan melalui ucapan atau perkataan dan melalui penahanan pemenuhan hak atau kebutuhan perempuan. Wujud kekerasan tidak langsung dapat berupa tindakan pembiaran atau pengabaian laki-laki, baik sebagai saudara, bapak, dan laki-laki lain terhadap perempuan, baik sebagai saudara, ibu, dan perempuan lain yang berada dalam kondisi keterpurukan atau menderita. Kekerasan dalam konteks ini dapat terjadi jika laki-laki tersebut mengabaikan atau melakukan 
devisisasi terhadap norma-norma dan nilai-nilai sosial demi mencapai tujuan tertentu. Temuan data berikut menggambarkan adanya hal tersebut.

"Bocah bagus... bocah pinter... anak Bapak, coba sekarang 41ading41t, kemana saja kalian berpetualang seharian!” Tandasnya dengan tegas.

"Dia yang mengajak, Pak" Rizal mencari alasan dengan menunjuk mukaku.

"Tetapi kamu mau. Salah sendiri, "aku tak mau kalah.

"O... jadi rupanya kamu yang punya inisiatif bocah wedhok. Kamu yang ngajari kakakmu jadi penyelam seperti ini ya? Kamu yang membujuk kakakmu mengembara?"(Khalieqy, 2009: 6).

Kutipan di atas menggambarkan adanya dominasi patriarki domistik konteks kekerasan tidak langsung yang dilakukakn oleh saudara laki-laki bernama Rizal terhadap saudara perempuan bernama Annisa dan laki-laki bapak terhadap anak perempuannya. Rizal telah melakukan pengalihan kesalahan dengan caramenunjuk ke arah muka Annisa bahwa Annisalah yang telah mengajak dirinya pergi menyelam, padahal kepergian mereka atas kemauan bersama. Rizal dalam hal ini memanfaatkan kuasa sebagai saudara laki-laki untuk menyelamatkan diri dari amarah bapaknya. Laki-laki bapak memiliki hak penuh atas keputusan untuk memfonis bahwa Annisalah yang bersalah dengan caramenerima begitu saja keterangan dari anak laki-lakinya serta tidak memberi kesempatan kepada Annisa untuk menjelaskan. Laki-laki bapak dalam hal ini sekaligus melakukan kekerasan tidak langsung dalam nuansa dominasi patriarki berupa pengabaian atas 41ading41t Annisa dan pembiaran terhadap tuduhan Rizal atas kesalahan Annisa.

"Hanya ke blumbung dekat sawah, soalnya lek Khudori tidak ada. Tadinya mau belajar naik kuda sama dia."

"Siapa yang mau belajar naik kuda? kau, bocah wedhok?"

"Iya.Memangnya kenapa, Pak? tidak boleh? Kak Rizal juga belajar naik kuda".

"Ow...ow....ow... jadi begitu. apa Ibu belum mengatakan padamu kalau naik kuda hanya pantas dipelajarai oleh Kakakmu Rizal, atau Kakakmu Wildan. Kau tahu, mengapa?Sebab kau ini anak perempuan, Nisa.Nggak pantas, anak perempuan kok naik kuda, pencilakan, apalagi keluyuran mengelilingi 41ading, sampai ke blumbang segala. Memalukan! kau ini sudah besar masih bodoh juga, hehh!!" Tasbih bapak bergerak lamban, mengena kepalaku (Khalieqy, 2009: 7)

Laki-laki bapak bukan hanya melakukan pengabaian dan pembiaran, namun secara implisit ia telah memosisikan diri sebagai orang yang paling berkuasa dan paling benar dalam memutuskan suatu perkara. Laki-laki bapak dalam kutipan di atas mengisyaratkan adanya praktik dominasi patriarki domistik konteks kekerasan tidak langsung karena ia memperlakukan tidak adil terhadap Annisa dibandingkan dengan Rizal. Laki-laki bapak memfonis bahwa belajar naik kuda hanya berlaku bagi lakilaki, sedangkan peempuan dianggap tidak pantas dan memalukan, bahkan ia mengucapkan kata-kata "sudah besar masih bodoh" yang dapat mengganggu kejiwaan dan perasaan sebagai anak perempuan.

Dominasi yang dilakukan sang bapak terhadap Annisa semakin memberatkan Annisa untuk melakukan aktivitas keseharian karena sang bapak melakukan kekerasan secara tidak langsung sebagai wujud dominasi patriarki domistik. Sang bapak membatasi dan memasung kebebasan Annisa sebagai bagian dari pembunuhan karakter, yakni dengan cara membuat pagar baru yang lebih tinggi dan sempit, hingga daya pandang terasa lebih tertutup baginya. Sementara, posisinya sebagai perempuan semakin terpuruk karena ia dinisbatkan sebagai perempuan yang harus menyelesaikan segala pekerjaan di dapur yang dipenuhi bau asap dan bau bawang. Ia pun harus mempersiapkan masakan untuk kepentingan lakilaki, baik sebagai saudara maupun sebagai bapak, yang tak pernah berpikir dan merasakan bagaimana proses menyelesaikan masakan itu. Dominasi patriarki domistik konteks kekerasan secara tidak langsung tampak sekali, yakni terabaikannya kebebasan Annisa untuk dapat menikmati hari-hari seperti yang dirasakan oleh saudara laki-lakinya, termasuk dalam menikmati sarapan pagi seperti yang dirasakan oleh bapak dan saudara laki-lakinya.Gambaran tersebut ditunjukkan oleh kutipan teks berikut.

"Ruang bermainku mendapat pagar baru, lebih tinggi dan sempit untuk cakrawala penglihatanku. Tanganku mulai dilatih memegang piring, gelas, sendok, wajan, dan api pembakaran. Bau asap membuatku pusing dan tersedak bertubi-tubi. bau bawang dan sambal terong membuatku bersinbersin. Sampai lidahku tak pernah bisa menikmati sarapan pagi, bahkan tak juga merasakan kebebasan ketika kedua tangan ini mesti kembali mencuci piring yang dipenuhi minyak bekas makanan Rizal, wildan dan bapak terus saja duduk di meja makan sambil ngobrol dan berdahak. (Khalieqy, 2009: 8-9)

Dominasi patriarki domistik konteks kekerasan tidak langsung berupa pengabaian atas perempuan terjadi pula ketika laki-laki bapak dan saudara tidak pernah memberi kesempatan kepada Annisa untuk duduk bersama dan saling membagi cerita. Laki-laki bapak lebih berpihak pada anak laki- 
lakinya daripada anak perempuannya. Lebih parah lagi sang bapak selalu menyepelekan keberadaan Annisa dalam keluarga karena ia tidak diajak untuk duduk bersama dan bercerita bersama, bahkan mereka secara tidak langsung menyinggung perasaan Annisa dengan menutup mulut ketika Annisa datang mendekatinya. Pernyataan tersebut dipertegas oleh adanya kutipan berikut.

"Bapak akan terbahak-bahak manakala Rizal mampu membawakan cerita petualangan baru yang seru dan lucu. Tetapi begitu aku datang di antara mereka, semuanya jadi terdiam.

"Kenapa sih? kalian pikir aku ini hantu? Kok semuanya tiba-tiba diam? Pasti sedang ngerasani aku, ya."

"Lho,lho,lho...kok malah su'udzon,"kata bapak sambil mengusap rambutku. Aku jengkel dan merasa disepelekan, segera menepiskannya (Khalieqy, 2009: 9).

Bentuk pengabaian lainyang menjurus pada munculnya ketersinggungan perasaan terjadi saat Wildan sebagai saudara laki-laki berkata kepada Annisa bahwa mereka bicara urusan laki-laki dan perempuan tidak boleh tahu. Laki-laki dalam hal ini ingin menang sendiri dengan tanpa memberi kesempatan kepada saudara perempuannya sekaligus laki-laki bapak maupun saudara tidak pernah memberikan kesempatan kepada Annisa untuk berbicara lebih banyak, sementara mereka pada dasarnya sama-sama memiliki hak berbicara.Pola pikir yang dibangun oleh laki-laki bapak dan saudara tersebut dapat dikategorikan sebagai bentuk pendominasian dalam konteks kekerasan tidak langsung.Hal yang demikian tercermin pada kutipan berikut.

"Jangan begitu, Nisa. Kita kan sedang bicara urusan laki-laki," tambah Wildan.

"Memangnya urusan laki-laki itu apa? Apa perempuan tak boleh mengetahuinya?"

Seperti pagi yang lain, aku tak pernah mendapatken kesempatan untuk berbicara lebih banyak. Kecuali bersiap diri dan berangkat bersama rizal menuju ke sekolah yang tidak begitu jauh dari rumah kami. (Khalieqy, 2009: 10)

Penguasaan laki-laki atas perempuan atau penenpatan posisi kepentingan laki-laki dibandingkan dengan perempuan dalam konteks kekerasan tidak langsung ditunjukkan pula oleh laki-laki lain. Hal ini dapat dilihat dari kutipan berikut, yakni kutipan yang mengambarkan adanya pendominasian laki-laki atas perempuan, yang diucapkan oleh laki-laki lain sebagai guru terhadap perempuan sebagai muridnya. Sang guru secara tidak langsung memasung pola pikir siswa untuk melegatimasi adat istiadat dalam budaya nenek moyang yang menempatkkan posisi kepentingan laki-laki lebih tinggi karena menurutnya, laki-laki cenderung dan berpotensi untuk bergerak di ranah publik, sedangkan perempuan lebih tepat dan dinisbatkan sebagai makhluk yang berada di ranah domistik. Kutipan berikut memperkuat adanya pernyataan tersebut.

"Baiklah anak-anak," pak guru mencoba menguasai suasan, "Dalam adat istiadat kita, dalam budaya nenek moyang kita, sesorang laki-laki memiliki kewajiban dan seorang perempuan juga memiliki kewajiban. Kewajiban seorang laki-laki, yang terutama adalah bekerja mencari nafkah, baik di kantor, di sawah, di laut atau dimana saja asal bisa mendatangkan rezeki halal. Sedangkan seorang perempuan, mereka juga memiliki kewajiban, terutama adalah mengurus urusan rumah tangga dan mendidik anak. Jadi memasak, mencuci, mengepel, menyetrika, menyapu, dan merapikan seluruh rumah adalah kewajiban seorang perempuan. Demikian juga memandikan anak, menyuapi, menggantikan popok dan menyusui, itu juga kewajiban seorang perempuan. sudah paham, anak-anak...?

(Khalieqy, 2009: 12)

Kekerasan tidak langsung dalam nuansa dominasi patriarki domistik dapat terjadi melalui perilaku dan tindakan yang dapat menyakiti perasaan, meskipun tidak dilakukan secara sentuhan badan. Hal ini dilakukan oleh saudara laki-laki bernama Wildan dan Rizal yang merasa berada di atas angin, sehingga bebas untuk melakukan apa yang diinginkan, misalnya tidur kembali sehabis shubuh demi pemenuhan kepentingan. Perilaku dan tindakan kedua laki-laki tersebut menyebabkan munculnya rasa marah Annisa, yang secara tidak langsung menimbulkan ketertekanan jiwa. Munculnya ketertekanan jiwa itu sebagai dampak adanya dominasi patriarki domistik konteks kekerasan secara tidak langsung, yang secara gambling tersirat pada kutipan berikut.

"Menghapus amarah? Memangnya Nisa selalu marah sehabis subuh?"

"Benar, mbak.Habis Rizal dan wildan boleh kembali tidur, sementara Nisa harus membersihkan tempat tidur, dan membantu ibu memasak di dapur.Sementara Rizal dan Wildan masuk lagi ke kamar, katanya mau belajar, padahal Nisa lihat sendiri mereka kembali tidur sehabis shalat shubuh."(Khalieqy, 2009: 21). 


\section{Simpulan}

Berdasarkan hasil analisis tentang patriarki domestik Perempuan Berkalung Sorban dapat disimpulkan sebagai berikut: (1) Patriarki domestik konteks kekerasan secara langsung ditandai oleh adanya kekerasan laki-laki sebagai suami terhadap perempuan sebagai istri yang bersifat fisik dengan maksud dan tujuan untuk merusak, melukai, dan menghancurkan bagian tubuh perempuan, baik dengan tangan, kaki, dan tubuh. Kekerasan tindakan, perbuatan, dan perilaku laki-laki tersebut dimaksudkan untuk melegatimasi adanya kekuasaan laki-laki atas perempuan, sehingga terbangun citra bahwa laki-laki lebih penting dibandingkan perempuan. (2) Patriarki domestik konteks kekerasan secara tidak langsung ditandai oleh adanya tindakan, perbuatan, dan perilaku nonfisik laki-laki, baik sebagai bapak, saudara, dan laki-laki lain terhadap perempuan, baik sebagai anak, saudara, maupun perempuan lain. Dengan maksud dan tujuan untuk mempengaruhi pola pikir, psikis, mental, dan kejiwaan melalui ucapan verbal bernuansa kotor dan tak layak atau keluar dari norma kesusilaan dan keagamaan, sehingga anak atau saudari atau perempuan lain tersinggung perasaannya, tertahan pemenuhan haknya, terpasung kebebasannya, terabaikan, terkekang, dan tertindas atau dimaksudkan untuk melegatimasi adanya kekuasaan laki-laki atas perempuan, sehingga terbangun citra bahwa laki-laki lebih penting dibandingkan perempuan.

\section{Referensi}

Ahmadi, Abu. 2007. Psikologis Sosial.Jakarta: Rineka Cipta. Arikunto, Suharsimi. 2006. Prosedur Penelitian: Suatu Penelitian Praktik. Bungin, M. Burhan. 2010. Penelitian Kualitatif. Jakarta: Kencana. Ciciek, Farha. 2005. Jangan Ada Lagi Kekerasan dalam Rumah Tangga. Jakarta: Gramedia Pustaka Utama. Darma, Yoce Aliah. 2009. Analisis Wacana Kritis.Bandung: Yrama Widya.

El-Khalieqy, Abidah. 2009. Perempuan Berkalung Sorban. Yogyakarta: Arti Bumi Intaran. Emzir dan Syaifur Rohman. 2015.Teori dan Pengajaran Sastra. Jakarta: Raja Grafindo Persada. Endraswara. 2011. Metodologi Penelitian Sastra. Yogjakarta: CAPS Jakarta: Depdikbud. Jenks, Chris. 2013. Culture : Studi Kebudayaan. Yogyakarta : Pustaka Pelajar Kosasih, E. 2012. Dasar-dasar Keterampilan Bersastra. Bandung: Yrama Widya. Kurniawan, Heru. 2012. Teori, Metode, dan Aplikasi Sosiologi Sastra. Yogyakarta: Cahaya Ilmu. Moleong, Lexy J. 2005. Metodelogi Penelitian Kualitatif. Bandung: Remaja Rosda Karya. Nurgiyantoro, Burhan.2010. Teori Pengkajian Fiksi. Yogyakarta: Gadjah Mada: Universitas Press. Ratna, Nyoman Kutha. 2013. Paradigma Sosiologi Sastra. Yogyakarta : PustakaPelajar Scott, John. 2011. Sosiologi The Key Concepts. Jakarta: Raja Grafindo Persada. Sugihastuti. 2009. Teori Apresiasi Sastra. Yogyakarta: Pustaka Pelajar. Suharto dan Sugihastuti. 2010. Kritik Sastra Feminis: Teori dan Aplikasinya.Yogyakarta: Pustaka Pelajar. Sujinah.2015. Pedoman Penulisan Tesis dan Artikel Ilmiah.Surabaya: Muhammadiyah University Press. Sunanto, K. 2011. Sosiologi Perubahan Sosial. Jakarta: Raja Grafindo Persada. 